ORIGINAL ARTICLE

\title{
Infantile Blount's Disease: A case report of 3 years old female baby of Zhob, Pakistan
}

\author{
SUMERA AKRAM ${ }^{1}$, MUHAMMAD AHMED KHAN² \\ ${ }^{1}$ Child Specialist $D H Q$ Hospital Zhob \\ ${ }^{2} \mathrm{CMH}$ Zhob \\ Correspondence to Dr. Muhammad Ahmed Khan, Email: akawan79@gmail.com, Cell: 0333-4421977
}

\begin{abstract}
Background; Blount's disease is a rare developmental disorder of children which causes progressive bowing of lower limbs. The term "Blount" was named after American orthopedic surgeon "Walter Putnam Blount" who first described this condition. The etiology of Blount's disease is unknown but believed to be multifactorial. Various predisposing factors have been attributed including obesity, early walking, race, pre-existing varus, increased pressure on growth plate and nutrition. Blount's disease has been suggested to be more frequent in African, Afro-american populations. Blount's disease has to be differentiated from physiological bowing (physiologic genu varum) and rickets. Early diagnosis and treatment of Blount's disease is essential as the disease process is reversible in early stage.

Case; A three years old female child was brought by her mother with complaint of progressive bowing of both lower limbs for last one year. She achieved her milestones at appropriate age and started walking at 11 months of age without support. On examination, her height was $90 \mathrm{cms}$ (at $10^{\text {th }}$ centile) and weight was $17 \mathrm{kgs}$ (at $90^{\text {th }}$ centile). BMI (body mass index) was 20.9 (obese). There were no clinical signs or symptoms of rickets i.e frontal bossing, wide wrist, rachitic rosary, carpopedal spasm, fits or muscle weakness etc. Roentgenogram showed tibia in varus with a peculiar beak at metaphysic and raised metaphyseal-diaphyseal angle $(>16$ degrees). Serum calcium and serum vitamin D (25-hydroxy vitamin D) were normal. Serum alkaline phosphatase level was raised. Keeping in view typical history, examination findings and radiological epiphyseal beaking along with raised metaphyseal-diaphyseal angle, diagnosis of Infantile Blount's disease was made.

Conclusion; The clinicians should have a high suspicion of infantile blount's disease when a child, more than 3 year's age presents with severe varus deformity at proximal tibia with typical radiological findings. Characteristic radiologic findings along with history and examination help to distinguish it from physiologic bowing (physiologic genu varum) and rickets.

Keywords; Blount's disease, Physiologic genu varum, Rickets, Tibia vara, Osteochondrosis deformans tibiae
\end{abstract}

\section{INTRODUCTION}

Blount disease is a growth disorder of tibia that results in internal rotation, tibial bowing and beaking of posteromedial proximal tibia ${ }^{1,2}$. The term "Blount" was named after American orthopedic surgeon "Walter Putnam Blount" who first described this condition ${ }^{3}$. It is also called 'tibia vara', 'osteochondrosis deformans tibiae' or Mau-Nilsonne Syndrome. Three different types of Blount disease have been described depending upon age of presentation. Infantile, juvenile and adolescent Blount disease. Infantile, also known as early onset arises before the age of 4 years. Juvenile variant develops between $4-10$ years of age. Adolescent type (late onset) develops after 10 years of $\mathrm{age}^{2,4}$. The etiology of Blount's disease is unknown but believed to be multifactorial. Various predisposing factors have been attributed including obesity, early walking, race, pre-existing varus, increased pressure on growth plate and possibly nutrition ${ }^{2,5}$. Blount's disease has been suggested to be more frequent in African, Afro-American as compared to Caucasians population ${ }^{6,7}$. Few authors have suggested genetic predisposition ${ }^{8}$. Researchers have shown positive family history in $14 \%$ to $45 \%$ cases of infantile Blount's disease and negated familial pattern of adolescent variant of disease ${ }^{9,10}$. Plain roentgenogram (X-ray) is sufficient to

Received on 14-03-2021

Accepted on 27-07-2021 diagnose Blount's disease in patient older than 2.5 years of age $^{11}$. Early diagnosis and treatment of Blount's disease is essential as this disease process is reversible in early stage. Blount's disease has to be differentiated from physiological bowing (physiologic genu varum) and rickets. Cases of physiological bowing grow out of the disease by 18-24 months of age ${ }^{12}$. Tibial metaphyseal-diaphyseal angle in physiological bowing is $<11$ degrees compared to $>16$ degrees in Blount's disease ${ }^{12}$. In rickets, the children have low serum calcium, serum vitamin $D$ and high level of alkaline phosphatase along with frontal bossing, rachitic rosary and wide wrists. Radiologic findings in rickets include widening, fraying and cupping of metaphyseal region. Management of Blount's disease depends upon age at presentation and severity of disease. Conservative management along with bracing has shown promising results in early stage. Cases refractory to conservative management and bracing, proximal tibial osteotomy is recommended ${ }^{13}$. Management of severe and neglected cases can be challenging for orthopedic surgeons and may require multiple combination surgical procedures.

\section{CASE}

A three years old female child was brought by her mother in the outpatient department of District Headquarter Hospital Zhob with complaint of progressive bowing of both lower limbs for last one year. She had been exclusively 
breast-fed for 08 months. Weaning was introduced late and lacked diversity of solid foods. Her prenatal and postnatal history was uneventful. Her birth weight was 3.5 kilograms. She achieved her milestones at appropriate age and started walking at 11 months of age without support. On examination, her height was $90 \mathrm{cms}$ (at $10^{\text {th }}$ centile) and weight was $17 \mathrm{kgs}$ (at $90^{\text {th }}$ centile). BMI (body mass index) was 20.9 (obese). There were no clinical signs or symptoms of rickets i.e. frontal bossing, wide wrist, rachitic rosary, carpopedal spasm, fits or muscle weakness etc. Her spleen or liver were not palpable. Rest of systemic examination was normal. There was no history of similar complaints in any other family member. She had been treated as a case of rickets and prescribed calcium supplements and vitamin D multiple times during last year with no benefit. She was advised roentgenogram, serum calcium, serum phosphate, serum vitamin D (25-hydroxy vitamin D) and serum alkaline phosphatase levels. Roentgenogram showed tibia in varus with a peculiar beak at metaphysic and raised metaphyseal-diaphyseal angle (>16 degrees). Serum calcium $(2.3 \mathrm{mmol} / \mathrm{L})$ and serum vitamin D (25-hydroxy vitamin D) were normal $(33 \mathrm{ng} / \mathrm{mL})$. Serum alkaline phosphatase level was raised (832U/L) as shown in Table 1. Keeping in view typical history, examination findings and radiological epiphyseal beaking along with raised metaphyseal-diaphyseal angle, diagnosis of Infantile Blount's disease was made. The patient has been now referred to orthopedic department of tertiary care hospital for management of Blount's disease.

Table 1: Laboratory investigations

\begin{tabular}{|l|c|c|c|}
\hline Investigation & Normal value & Patient value & Remarks \\
\hline Hemoglobin & $12-18 \mathrm{mg} / \mathrm{dL}$ & $11.3 \mathrm{gm} / \mathrm{dL}$ & Normal \\
\hline White cell count & $4-11 \times 10^{3} \mathrm{uL}$ & $6.5 \times 10^{3} \mathrm{uL}$ & Normal \\
\hline Platelet count & $150-400 \times 10^{3} \mathrm{uL}$ & $221 \times 10^{3} \mathrm{uL}$ & Normal \\
\hline Serum calcium & $2-2-2.7 \mathrm{mmol} / \mathrm{L}$ & $2.3 \mathrm{mmol} / \mathrm{L}$ & Normal \\
\hline Serum phosphate & $1.4-2.1 \mathrm{mmol} / \mathrm{L}$ & $1.5 \mathrm{mmol} / \mathrm{L}$ & Raised \\
\hline Serum Vitamin D 25(OH) D & $20-50 \mathrm{ng} / \mathrm{mL}$ & $33 \mathrm{ng} / \mathrm{mL}$ & $832 \mathrm{U} / \mathrm{L}$ \\
\hline Serum alkaline phosphatase & $\begin{array}{l}\text { Adult }(65-306 \mathrm{U} / \mathrm{L}) \\
\text { Child }(65-644 \mathrm{U} / \mathrm{L})\end{array}$ & 8 \\
\hline
\end{tabular}

Fig 1. X-ray of tibial varus deformity and epipheal beak and bowing

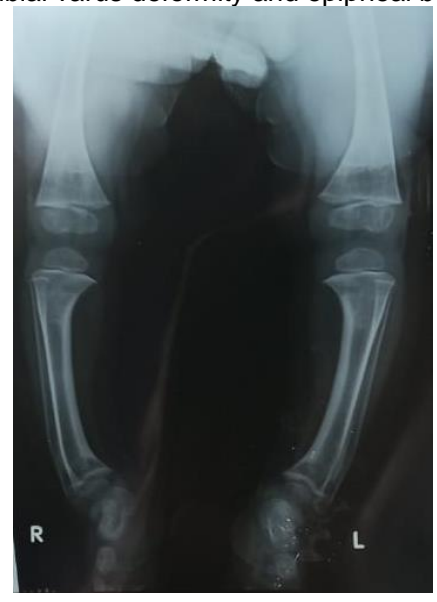

\section{DISCUSSION}

Many cases of this disease have been reported worldwide since it was first invented by Walter Putnam Blount ${ }^{3}$. Prevalence of Blount's disease remains unknown. Jensen $\mathrm{N}$. et al. studied 139 cases of Blount's disease in Ghana from 2010 to 2018 . $90 \%$ of cases belonged to a particular tribe known as "Akan Tribe". Familial predisposition (positive family history) was seen in $62 \%$ of cases. Jansen et al have reported the highest number of cases of Blount's disease so far.

Giwa et al studied 15 cases of Blount's disease in Nigeria and showed significant increase in serum alkaline phosphatase as compared to control group ${ }^{13}$. The finding is similar to our case whose alkaline phosphatase was also raised. There is also increased alkaline phasphatase in rickets but typical radiological findings distinguish between the two diseases. Infantile Blount's disease also has to be differentiated from physiological bowing (physiologic genu varum). Cases with physiological bowing (physiologic genu varum) gradually improve over time in contrast to persistence/progression of condition in Blount's disease ${ }^{2,5}$.

It is vital to pick this disease early and distinguish it from physiological bowing and rickets to prevent irreversible outcome in the affected cases. Untreated and neglected cases can have lifelong gait deformities, limb length discrepancies and arthritis of knees ${ }^{12}$.

\section{CONCLUSION}

The clinicians should have a high suspicion of infantile blount's disease when a child, more than 3 year's age presents with severe varus deformity at proximal tibia with typical radiological findings. Characteristic radiologic findings along with history and examination help to distinguish it from physiologic bowing (physiologic genu varum) and rickets.

\section{REFERENCES}

1. Hollman F, Vroeman P. Infantile Blount's disease: histopathological changes in the proximal tibial metaphysic, comparison between medial and lateral specimens. Int $\mathrm{J}$ Pediatr Res 2016; 2: 025.

2. Jansen N, Hollman F, Bovendeert F, Moh P, Stegmann A, Staal HM. Blount disease and familial inheritance in Ghana, area cross-sectional study. BMJ Pediatrics Open 2021; 5: e001052. Doi: 10.1136/bmjpo-2021-001052.

3. Blount WP. Tibia vara osteochondrosis deformans tibiae. J Bone Joint Surg 1937; 19: 1-29.

4. Thompson GH, Carter JR. Late onset tibia vara (Blount's disease). Clin Orthop Relat Res 1990; 255: 24-35.

5. Banwarie RR, Hollman F, Meijs N, Arts JJ, Vroeman P, Moh $P$ et al. Insight into the possible aetiologies of Blount's disease: a systemic review of the literature. J Pediatr Ortho B 2020; 29: 323-36. 
6. Golding JSR, McNeil-Smith JDR. Observations on the etiology of tibia vara. J Bone Joint Surg Br 1963; 45-B: 3205.

7. Ho-Fung V, Jaimes C, Delgado J. MRI evaluation of knee in children with infantile Blount disease; Tibial and extra tibial findings . Pediatr Radiol 2013; 43: 1316-26.

8. Schmidt H, Mundlos S, Spranger JW. Sibs with a disorder resembling blount disease (tibia vara). Pediatr Radiol 1991; 21: 316-18.

9. Inaba Y, Saito T, Takamura K. Multicenter study of blount disease in Japan by the Japenese pediatric orthopedic association. J Orthop Sci 2014; 19: 132-40.
10. Schoenecker PL, Meada WC, Pierron RL. Blount's disease: a retrospective review and recommendations for treatment. $\mathrm{J}$ Pediatr Orthop 1985: 5: 181-6.

11. Janoyer M. Blount disease. Orthop Traumatol surg Res 2019; 105: S111-12.

12. Delnoitis I, Leidinger B, Kyriakou A, Galanis N. Blount's disease: Importance of early diagnosis and early treatment. Clin Case rep 2019; 7: 1454-5.

13. Sabharwal S, Sabharwal S. Treatment of infantile Blount disease: An update. J Pediatr Orthop 2017; 6: S26-31.

14. Giwa OG, Anetor JI, Alonge TO, Agbedana EO. Biochemical observations in Blount's disease ( Infantile tibia Vara). J Mat Med Assoc 2004; 96(9): 1203-7. 